\title{
凝集剂添加活性污泥法における リン除去プロセスの解析とそのモデル化
}

\author{
見島伊織1 ・ 中島淳2 \\ 1学生会員 工修 立命館大学大学院博士後期課程（テ525-8577 滋賀県草津市野路東1-1-1） \\ 2正会員 工博 立命館大学教授 理工学部環境システム工学科（テ525-8577 滋賀県草津市野路東1-1-1）
}

E-mail: jnakajim@nisiq.net

\begin{abstract}
凝集剤添加活性污泥法は安定したリン除去法として広範に用いられている方法である. しかし, 本法に おいての凝集剤添加量は経験的に決定されており，理論的な添加量の決定方法は報告されていない. 本論 文では室内実験により活性污泥中におけるリン除去用凝集剤の減少と蓄積，またそれに伴うリン除去特性 を検討する. さらにその結果をもとに污泥中の凝集剤およびリンを分別してとらえ，リン除去性能を有す る凝集剤とリンの凝集反応を表すリン除去モデルを提案した。 それによって，污泥中における凝集剤およ びリンの挙動を推定することが可能になり, リン除去モデルを用いることで凝集剤の最適添加量の決定に 応用することができる.
\end{abstract}

Key Words : phosphorus removal, activated sludge process, coagulation, coagulant content, phosphorus removal model

\section{1.はじめに}

湖沼や内湾などにおける富栄養化を防止するため に有機物の除去はもちろんのこと，栄養塩類の除去 が行われるようになってきた ${ }^{1)}$. 栄養塩類のうちリ ンが藻類増殖の制限因子となる場合が多く, 排水処 理過程でリンを除去することによって藻類の增殖を 抑制できる.

凝集剂添加活性污泥法は，下水のリン除去法とし て広く普及している ${ }^{2), 3)}$ 。また, 生物脱リン （EBPR）法で運転されている施設において, リン 除去性能の安定化のために活性污泥に凝集剤が添加 される事例がみられる ${ }^{2), 4)}$. さらに, 活性污泥一の 凝集剤の添加は污泥の沈降性を向上させることが知 られている ${ }^{4)-6)}$.このようなことから, 凝集㓮の活 性污泥への添加は今後さらに増加すると考えられる. しかしながら, 污泥一の凝集剤の添加により運転コ ストおよび污泥発生量が増加する ${ }^{3), 77-9)}$.

凝集剂である $\mathrm{Fe}$ 塩, $\mathrm{Al}$ 塩を活性污泥に添加する と, 下水中の $\mathrm{PO}_{4}-\mathrm{P}$ と結合し, $\mathrm{FePO}_{4}$ または $\mathrm{AlPO}_{4}$ を生成するといわれている ${ }^{3,8)-10)}$. よって, 基本的 にはリン 1 モルに対し凝集剂 1 モルの添加が必要と いえる. しかし, 添加した凝集剤はすべて $\mathrm{PO}_{4}-\mathrm{P}$ と
結合するのではなく, 同時に水酸基イオンが $\mathrm{Fe}$ や $\mathrm{Al}$ と反応し, $\mathrm{Fe}(\mathrm{OH})_{3}, \mathrm{Al}(\mathrm{OH})_{3}$ などの沈殿を生じる といわれている ${ }^{3), 10)}$. そのため, 流入リン量に対し て多めの凝集剤の添加が必要となり, 流入リン量に 対してモル比で 1 3 必要とされている ${ }^{3,8), 10)}$. 一方 で, 凝集剤添加活性污泥法の実施設の多くにおいて は, 同時に窒素除去のための嫌気工程を有し, その ために非意図的に EBPR が生起している事例もみら れる ${ }^{11)}$ 。このような場合には, 活性污泥微生物によ ってかなりのリンが除去されるので, 凝集剤添加量 を削减した運転が可能と考えられる. 実際に, 少な い凝集剂添加量でも効果的なリン除去が得られ，そ れは EBPR によると考えられる事例が報告されてい $3^{5)}$. また, EBPR の安定のために, バックアップ 的に凝集郕が添加されている ${ }^{2,4), 12)}$.

凝集剤添加活性污泥法における最適な凝集剂添加 量の決定方法については, 未解明な点が残されてい る. また, EBPR法と凝集剂添加活性污泥法を組み 合わせ, 凝集剤添加量を検討した研究はみられない. 筆者らはEBPR 凝集剤によるリン除去のメカニズ 厶を詳細に把握し, 最適な凝集剤添加方法を求める ことを最終目標としている. 本論文では, その前段 階として凝集剂添加活性污泥法に関する基礎的な知 
見を得るために, 污泥中の凝集剤の挙動について室 内実験を行った。 それにより, 活性污泥一の凝集剂 の添加に伴う污泥中の凝集剂含有率の変動特性とリ ン除去性能との関係を考察した。 また, その結果か ら, 最適な凝集剤添加量を求めるためのリン除去モ デルを提案した.

\section{2. 実験方法}

\section{（1）污泥中凝集剤の減少}

曝気槽（容量 2.9L）と沈殿槽からなる完全混合型 の活性污泥室内実験装置を用い, 実処理場の活性污 泥を種污泥とした。凝集剤には塩化第 2 鉄（Fe とし て 300mg； Fe系）とポリ塩化アルミニウム（PAC）

（Al として $150 \mathrm{mg} ; \mathrm{Al}$ 系）を用い，運転開始時に それぞれを 1 回だけ添加した. 各凝集剤について,

Table 1 に示した 3 段階の運転を行い，それぞれを Run1〜Run6 とした. グルコースを主基質とする人 工下水（成分を Table 2 に示す）を Run1 および Run4 は 600 倍, Run2 および Run5 は 240 倍, Run3 および Run6 は 120 倍に水道水で希釈して $4 \mathrm{~L} / \mathrm{d}$ で曝 気槽に流入させた。実験は $25^{\circ} \mathrm{C}$ の恒温室内にて 30 分曝気 15 分停止の間欠曝気で約 1 ケ月間運転した。 污泥（曝気槽混合液）は Table 1 のように毎日引き 抜き, 処理水および曝気槽混合液を 1〜2 日ごとに 採取して分析した.

\section{（2）凝集剤の污泥への蓄積}

曝気槽（容量 4.0L） と沈殿槽からなる完全混合型
の活性污泥室内実験装置を用い，実処理場の活性污 泥を種污泥とし, 人工下水（Table 2 を 200 倍に希 釈）を $6 \mathrm{~L} / \mathrm{d}$ で流入させた。凝集剤には塩化第 2 鉄 を用い，（1）とは異なり連続添加した．添加量は $\mathrm{Fe} / \mathrm{P}$ モル比として $0,1 / 20,1 / 10,1 / 5,1 / 2,1,2$ の 7 段階とし，それぞれを Run7〜Run13 とした。曝気 は EBPR が生起しないように連続曝気運転とし， $25^{\circ} \mathrm{C}$ の恒温室内にて約 2 ヶ月間運転した。污泥（曝 気槽混合液）は Table 3 のように毎日引き抜き，1〜 3 日ごとに処理水および曝気槽混合液を採取して分 析した。 なお，結果の解析は処理が安定した 10 日 以降について行った.

\section{（3）分析項目および方法}

曝気槽混合液についてはMLSS, T-FeまたはT-Al, T-P（(2)のみ）を，処理水についてはSS, T-Feまた はT-Al, T-P, $\mathrm{PO}_{4}-\mathrm{P}$ ((2)のみ) をそれぞれ測定し た. T-FeおよびT-Alは硝酸・過酸化水素水にて分解 後, 原子吸光光度法またはICP法により測定し, そ の他はJIS K 0102および下水試験方法に従った.

\section{3. 結果と考察}

\section{（1）污泥中凝集剤の減少（Run1～Run6）}

a) MLSSおよびSRT

Run1〜Run6におけるMLSSとSRT（d）を, Table 4 に示した．BOD負荷が高いRunでMLSSが高い傾向 がみられたが, 各Runでの変動は小さく概ね一定で あった．SRTは污泥引き抜き量の多いRunで短く，

Table 1 Operational conditions in Run1 $\sim$ Run6.

\begin{tabular}{|c|c|c|c|c|c|c|c|c|c|c|}
\hline & \multirow{3}{*}{$\begin{array}{l}\begin{array}{l}\text { Volume } \\
\text { of } \\
\text { aeration } \\
\text { tank }\end{array}\end{array}$} & \multicolumn{3}{|c|}{ Coagulant } & \multirow{2}{*}{ Flow rate } & \multicolumn{2}{|c|}{ Influent } & \multirow{2}{*}{ BOD load } & \multirow{2}{*}{ Excess sludge } & \multirow{2}{*}{ SRT } \\
\hline & & \multirow[b]{2}{*}{ Type } & \multirow[b]{2}{*}{ Additional method } & \multirow[b]{2}{*}{ Amount } & & BOD & $P$ & & & \\
\hline & & & & & $\mathrm{L} / \mathrm{d}$ & $\mathrm{mg} / \mathrm{L}$ & $\mathrm{mg} / \mathrm{L}$ & $\begin{array}{c}\mathrm{kgBOD} \\
/ \mathrm{m}^{3} / \mathrm{d}\end{array}$ & $\mathrm{mL} / \mathrm{d}$ & d \\
\hline Run1 & \multirow{6}{*}{$2.9 \mathrm{~L}$} & \multirow{3}{*}{$\mathrm{FeCl}_{3}$} & \multirow{6}{*}{$\begin{array}{l}\text { Instantaneously } \\
\text { addition at the } \\
\text { bigining of } \\
\text { experiment }\end{array}$} & \multirow{3}{*}{$300 \mathrm{mgFe}$} & \multirow{6}{*}{4} & 100 & 2.5 & 0.2 & 100 & 29 \\
\hline Run2 & & & & & & 250 & 6.3 & 0.5 & 150 & 19 \\
\hline Run3 & & & & & & 500 & 12.5 & 1.0 & 300 & 10 \\
\hline Run4 & & \multirow{3}{*}{ PAC } & & \multirow{3}{*}{$150 \mathrm{mgAl}$} & & 100 & 2.5 & 0.2 & 100 & 29 \\
\hline Run5 & & & & & & 250 & 6.3 & 0.5 & 150 & 19 \\
\hline Run6 & & & & & & 500 & 12.5 & 1.0 & 300 & 10 \\
\hline
\end{tabular}

Table 2 Concentration of the synthetic wastewater.

\begin{tabular}{lccr}
\hline Glucose & 50 & $\mathrm{~K}_{2} \mathrm{HPO}_{4}$ & 6.4 \\
Sodium glutamate & 50 & $\mathrm{KH}_{2} \mathrm{PO}_{4}$ & 1.6 \\
$\left(\mathrm{NH}_{4}\right)_{2} \mathrm{SO}_{4}$ & 50 & $\mathrm{NaHCO}_{3}$ & 63 \\
$\mathrm{NaCl}$ & 1.0 & & \\
$\mathrm{CaCl}_{2}$ & 0.5 & & \\
$\mathrm{MgSO}_{4}$ & 0.3 & & unit : $\mathrm{g} / \mathrm{L}$ \\
\hline
\end{tabular}


9d〜24dの範囲であった.

\section{b) リン除去特性}

$\mathrm{Fe}$ 系, $\mathrm{Al}$ 系の処理水 T-P の変化はそれぞれ Fig. 1 のとおりで, 運転開始時（凝集剤添加直後）には低 濃度であったが日数が経過するにつれ徐々に上昇し， $\mathrm{Fe}$ 系では 15 日程度, $\mathrm{Al}$ 系では 7 日程度で一定とな った。このためリン除去率も, 凝集剤添加時には 80\%以上であったものが $30 \%$ 以下に低下した。この ように, 凝集剤の添加を停止しても処理水 T-P はす ぐには増加せず，一定期間リン除去性能を維持して いたが，こうした現象は一時的に凝集剂が添加され た実処理場においても観察された ${ }^{11)}$.このリン除去 性能の維持は, 污泥中に蓄積された凝集剂の効果と 考えられる. 寸なわち, 污泥中に残存する凝集剤は 污水中のリンを除去する能力を有するといえる. そ こで, 污泥中凝集剤含有率の減少について次に考察 した.

\section{c）污泥中凝集剤含有率}

処理水の凝集剤濃度は，ほぼすべての Run で
$1 \mathrm{mg} / \mathrm{L}$ 以下と低濃度であった。污泥中凝集剤含有率 ( $\mathrm{Fe}$ 系では $\mathrm{CFe}, \mathrm{Al}$ 系では $\mathrm{CAl}$, まとめて $\mathrm{CM}$ と表 記 ; mgMe/gSS) は, 式（1）により求めた.

$$
\mathrm{CM}=(\mathrm{AM}-\mathrm{DM}) / \mathrm{MLSS} \cdot 1000
$$

ここで AM は曝気槽混合液中の凝集剤濃度（mg/L）， $\mathrm{DM}$ は処理水中の凝集剤濃度 $(\mathrm{mg} / \mathrm{L}), \mathrm{MLSS}$ は曝 気槽混合液 $\mathrm{SS}(\mathrm{mg} / \mathrm{L})$ である. $\mathrm{Fe}$ 系および $\mathrm{Al}$ 系 CM の変化はそれぞれ Fig. 2 のとおりで，すべての Run で初期には急激に後期には緩やかに減少した.

CM の減少を指数関数として式（2）で近似し， 減少の速度定数 $\mathrm{k}(1 / \mathrm{d})$ を求めた. ただし, $\mathrm{CM}_{0}$ は 運転開始時の CM である.

$$
\mathrm{CM}=\mathrm{CM}_{0} \cdot \exp (-\mathrm{kt})
$$

また, 活性污泥のみかけの比增殖速度 $\mu(1 / \mathrm{d}$; $=1 / \mathrm{SRT}$ ）を式（3）により求めた. ただし $\mathrm{V}$ は曝気

\begin{tabular}{|c|c|c|c|c|c|c|c|c|c|c|c|}
\hline & \multirow{3}{*}{$\begin{array}{c}\text { Volume } \\
\text { of } \\
\text { aeration } \\
\text { tank }\end{array}$} & \multicolumn{4}{|c|}{ Coagulant } & \multirow{2}{*}{ Flow rate } & \multicolumn{2}{|c|}{ Influent } & \multirow{2}{*}{ BOD load } & \multirow{2}{*}{ Excess sludge } & \multirow{2}{*}{ SRT } \\
\hline & & \multirow[b]{2}{*}{ Type } & \multirow{2}{*}{$\begin{array}{l}\text { Additional } \\
\text { method }\end{array}$} & \multirow[b]{2}{*}{ Molar ratio } & Amount & & BOD & $P$ & & & \\
\hline & & & & & $\mathrm{mg} / \mathrm{d}$ & $\mathrm{L} / \mathrm{d}$ & $\mathrm{mg} / \mathrm{L}$ & $\mathrm{mg} / \mathrm{L}$ & $\begin{array}{c}\text { kgBOD } \\
/ \mathrm{m}^{3} / \mathrm{d}\end{array}$ & $\mathrm{mL} / \mathrm{d}$ & d \\
\hline Run7 & \multirow{7}{*}{$4.0 \mathrm{~L}$} & \multirow{7}{*}{$\mathrm{FeCl}_{3}$} & \multirow{7}{*}{$\begin{array}{l}\text { Continual } \\
\text { addition }\end{array}$} & $\mathrm{Fe} / \mathrm{P}=0$ & 0 & \multirow{7}{*}{6} & \multirow{7}{*}{300} & \multirow{7}{*}{7.5} & \multirow{7}{*}{0.45} & \multirow{7}{*}{200} & \multirow{7}{*}{20} \\
\hline Run8 & & & & $\mathrm{Fe} / \mathrm{P}=1 / 20$ & 4 & & & & & & \\
\hline Run9 & & & & $\mathrm{Fe} / \mathrm{P}=1 / 10$ & 8 & & & & & & \\
\hline Run10 & & & & $\mathrm{Fe} / \mathrm{P}=1 / 5$ & 16 & & & & & & \\
\hline Run11 & & & & $\mathrm{Fe} / \mathrm{P}=1 / 2$ & 41 & & & & & & \\
\hline Run12 & & & & $\mathrm{Fe} / \mathrm{P}=1$ & 81 & & & & & & \\
\hline Run13 & & & & $\mathrm{Fe} / \mathrm{P}=2$ & 162 & & & & & & \\
\hline
\end{tabular}

Table 3 Operational conditions in Run7 Run 13.

\begin{tabular}{|c|c|c|c|c|c|c|c|c|c|c|c|c|c|c|c|c|c|c|}
\hline \multirow[b]{2}{*}{ MLSS (mg/L) } & \multicolumn{3}{|c|}{ Run 1} & \multicolumn{3}{|c|}{ Run2 } & \multicolumn{3}{|c|}{ Run3 } & \multicolumn{3}{|c|}{ Run4 } & \multicolumn{3}{|c|}{ Run5 } & \multicolumn{3}{|c|}{ Run6 } \\
\hline & 1200 & \pm & 210 & 2300 & \pm & 220 & 2800 & \pm & 240 & 1400 & \pm & 330 & 2100 & \pm & 250 & 2300 & \pm & 290 \\
\hline SRT (d) & 22 & \pm & 4 & 16 & \pm & 3 & 9 & \pm & 0 & 24 & \pm & 5 & 19 & \pm & 1 & 9 & \pm & 0 \\
\hline
\end{tabular}

Table 4 MLSS and SRT in Run1 Run6(Average \pm SD).
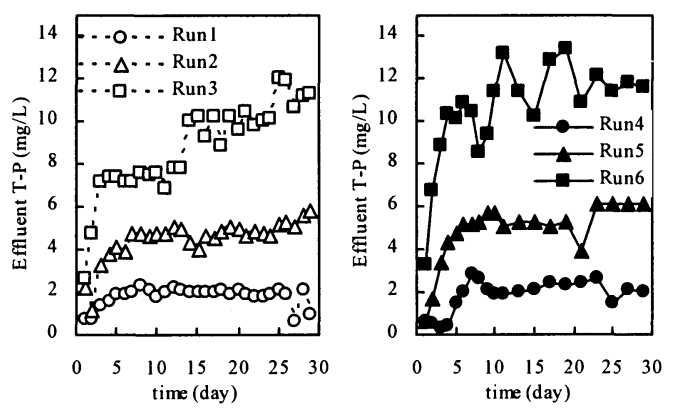

Fig. 1 Effluent T-P in Run1 $\sim$ Run3 (left) and Run4 Run6 (right).
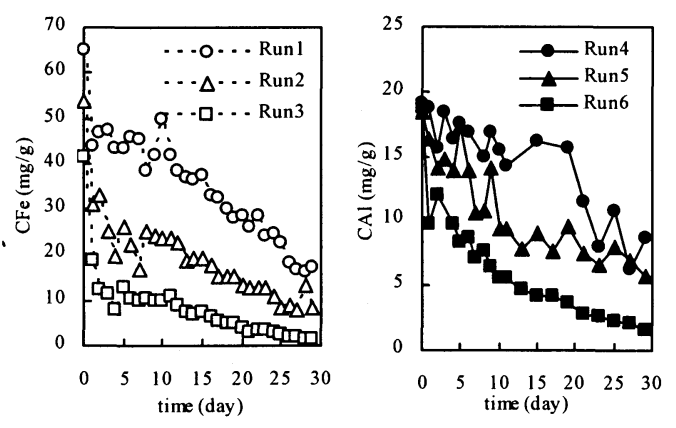

Fig. $2 \mathrm{CM}$ in Run1 $\sim$ Run3 (left) and Run4 Run6 (right). 
槽容量（L），Q は流入水量（L/d），Qw は余剩污 泥量 $(\mathrm{L} / \mathrm{d}), \mathrm{SS}$ は処理水 $\mathrm{SS}(\mathrm{mg} / \mathrm{L})$ である.

$$
\mu=(\mathrm{Qw} \cdot \mathrm{MLSS}+\mathrm{SS} \cdot \mathrm{Q}) /(\mathrm{MLSS} \cdot \mathrm{V})
$$

各 Runについて得られた k と $\mu$ のプロットは Fig. 3 のとおりで，ほぼ傾き 1 の直線上にある. Fig. 3 に は実処理場で得られた $\mathrm{k}$ と $\mu^{11)}$ についてもプロット したが，いずれの場合も $\mathrm{k}$ と $\mu$ はほぼ等しいとい える.

処理水の凝集剤濃度は低濃度であるので, $\mathrm{k}$ と $\mu$ がほぼ等しいことは, CFe または CAl が活性污泥の 增殖とその余剩污泥としての引き抜きにより希䣋さ れて減少したことを示唆している.

前にみたように, 污泥中に残存する凝集剤は污水 中のリンを除去する能力を有する. 余剩污泥の引き 抜きにより $\mathrm{CM}$ は減少し，Fig. 4 のように，それに 伴ってリン除去能力が低下したといえる.このこと から，リン除去性能は CM に梁く関連していること が示唆される. 実際, $\mathrm{CFe}$ と単位污泥重量当たりの リン除去量との関係は Fig. 5 のとおりで，各 Runに おいて CFe が大きいほどリン除去量が多いことがわ かる.

\section{（2）凝集剂の污泥への蓄積（Run7〜Run13）}

\section{a) MLSSおよびSRT}

各 Runにおける MLSS および SRT は，Table 5 の とおりであった. MLSS は Fe 無添加の Run7 で低く, 最も添加量が多い Run13 で高めであったが，Run8 〜Run12 ではほぼ同じであった。活性污泥への Fe 塩添加においては, 添加した $\mathrm{Fe}$ 重量の 3〜3.5 倍の

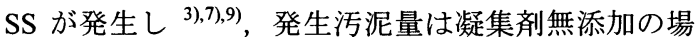
合と比べて 20〜30\%増すといわれている ${ }^{3), 13), 14) . こ ~}$ れらの事例では, Fe 添加量はリンに対してモル比 1 以上の添加が通常であるが，一方で EBPR のバック アップとしてより低いモル比の凝集剤を添加した例 では, 発生污泥量の増加はわずかであった ${ }^{12)}$. 本実 験の Run8〜Run12 ではモル比が 1 以下であったこと から，MLSS の顕著な増加がみられなかったと思わ れる.また，SRTは 17d〜19d の範囲であった.

b) リン除去特性

処理水 T-P および $\mathrm{PO}_{4}-\mathrm{P}$ は, 10 日目以降には各 Run でほぼ一定となった. 10 日目以降の処理水 T-P
平均值および標準偏差を凝集剤添加モル比（Fe/P） との関係で示すと Fig. 6 のとおりであり，凝集剤添 加モル比が大きいほど処理水 T-P が低かった．流入 リン量に対しモル比 1 および 2 の添加においては処 理水 T-P 平均值はそれぞれ $2.4,1.3 \mathrm{mg} / \mathrm{L}$ であった.

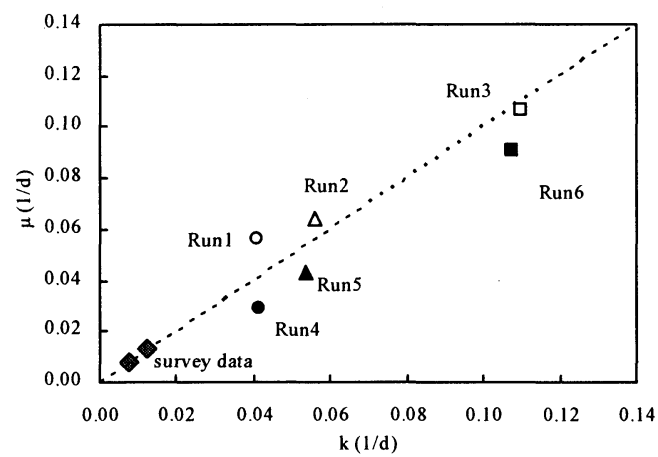

Fig. 3 Relationship between $\mathrm{k}$ and $\mu$.

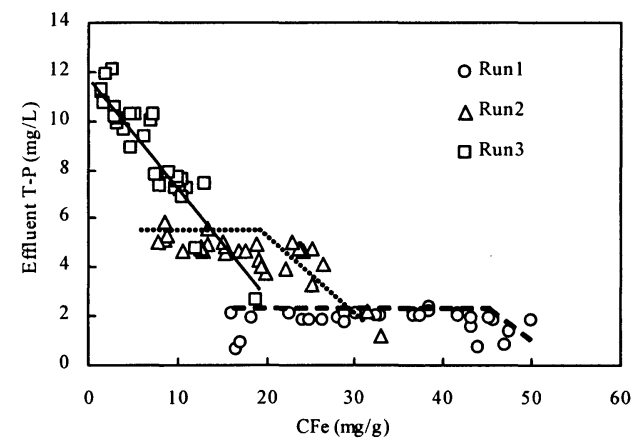

Fig. 4 Relationship between $\mathrm{CFe}$ and the effluent T-P in Run1 Run3.

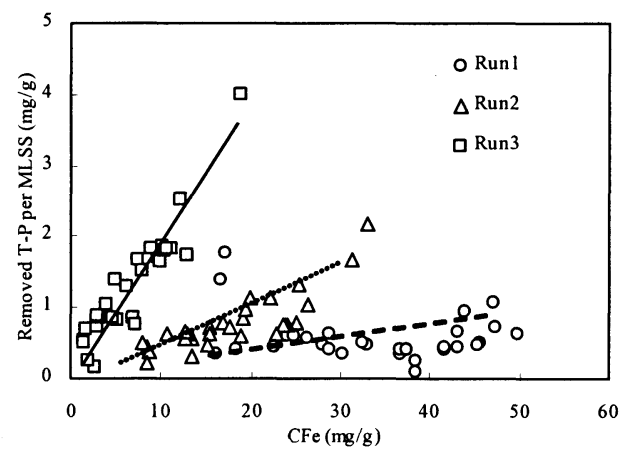

Fig. 5 Relationship between $\mathrm{CFe}$ and removed T-P per MLSS.

Table 5 MLSS and SRT in Run7 Run13 (Average \pm SD).

\begin{tabular}{|c|ccc|ccc|ccc|cc|cc|ccc|ccc|c|c|}
\hline & \multicolumn{2}{|c|}{ Run7 } & \multicolumn{2}{|c|}{ Run8 } & \multicolumn{2}{c|}{ Run9 } & \multicolumn{2}{c|}{ Run10 } & \multicolumn{2}{c|}{ Run11 } & \multicolumn{3}{c|}{ Run12 } & \multicolumn{2}{c|}{ Run13 } \\
\hline MLSS (mg/L) & 2200 & \pm & 420 & 2800 & \pm & 490 & 2700 & \pm & 470 & 2600 & \pm & 480 & 2700 & \pm & 430 & 2800 & \pm & 280 & 3200 & \pm & 440 \\
\hline SRT (d) & 17 & \pm & 2 & 19 & \pm & 1 & 19 & \pm & 1 & 18 & \pm & 1 & 17 & \pm & 1 & 17 & \pm & 1 & 18 & \pm & 1 \\
\hline
\end{tabular}


Yamamoto et al. ${ }^{13)}$ は, 高濃度の Fe 溶液を添加して 家庭排水における on-site 処理でのリン除去の検討を 行った. $\mathrm{Fe} / \mathrm{P}$ モル比 1 および 2 の凝集剂添加で処理 水 T-P 2.6, 1.0mg/L が得られており, これは我々の 結果と類似している.

\section{c）污泥中凝集剂およびリン含有率}

各 Run の CFe の変動は Fig. 7 のとおりで, すべて の Run で日数とともに上昇しほぼ一定になった。こ の実験では Fe を連続添加しており，添加による $\mathrm{Fe}$ の増加分と引き抜きによる $\mathrm{Fe}$ 减少分の差だけ $\mathrm{CFe}$ が増加したと考えられる. 添加量が引き抜き量より 多い期間は $\mathrm{CFe}$ が増加し続け，添加量と引き抜き量 が一致したところで CFe が一定になったと考えら れる. 処理水 T-P と CFe の関係は Fig. 8 のとおりで, CFe が高いほど処理水 T-P が低濃度に抑えられていた.

污泥中のリン含有率 $\mathrm{CP}(\mathrm{mgP} / \mathrm{gSS})$ CFe と同 様に求め, 時間変動を示すと Fig. 9 のとおりであっ た. 変動の大きな Runもみられたが, 全般に緩やか に上昇した後ほぼ一定となり, $\mathrm{CFe}$ の時間変動に類 似していた，ただし，Feの場合と異なり，リンの場 合は処理水への流出があるために，流入リン全量が

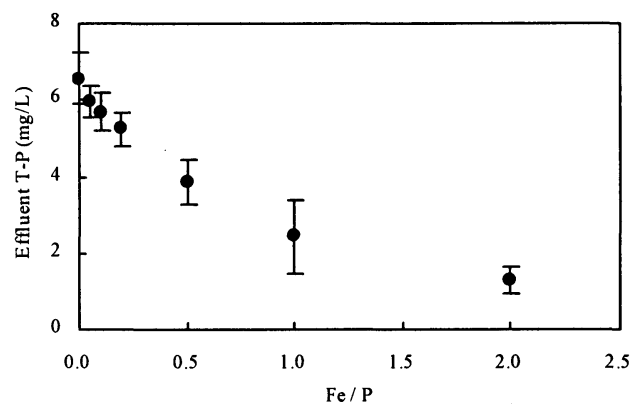

Fig. 6 Relationship between the molar ratio of the added $\mathrm{Fe}$ to the influent $\mathrm{P}$ and the effluent T-P (average and SD).

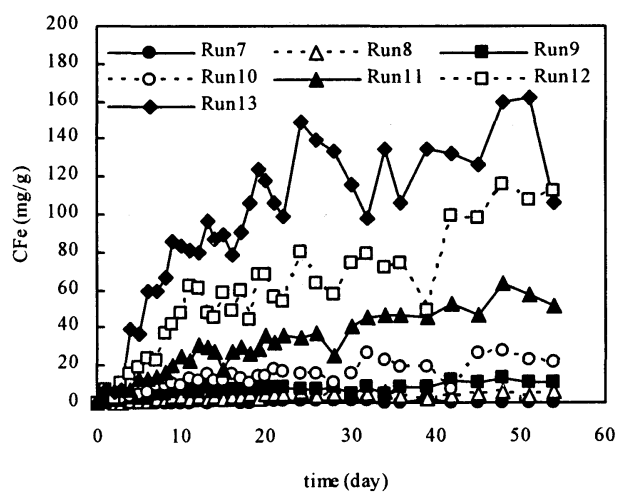

Fig. 7 Change of CFe.
污泥に移行してはいない.また, 運転開始時の $\mathrm{CFe}$ は $0 \mathrm{mg} / \mathrm{g}$ であるのに対し, CP は活性污泥微生物中 にリンを含有しているために，運転開始時にも $15 \mathrm{mg} / \mathrm{g}$ 程度存在した。このように, $\mathrm{Fe}$ とリンの変 動には違いがみられた。

\section{d）凝集による污泥へのリン移行量}

污泥へのリン移行量を, 流入水と処理水のリン負 荷量の差として求めた。凝集剂無添加の Run7 にお ける污泥へのリン移行量を, 微生物による攝取によ るものと考え, Run8〜Run13 のリン移行量からこの 微生物摂取分を減じたものを，凝集による污泥への リン移行量とした. 他方, 污泥への Fe 移行はす心゙ て凝集によるものと考え, 移行量は各 Runの流入水 と処理水の $\mathrm{Fe}$ 負荷量の差とした. 凝集により污泥 へ移行した Fe とリンのモル比を式（4）によって求 め $\Delta \mathrm{Fe} / \Delta \mathrm{P}$ とした.

$$
\Delta \mathrm{Fe} / \Delta \mathrm{P}=\mathrm{TrFe} /(\mathrm{TrP}-\mathrm{TrP} 7)
$$

ここで TrFe は污泥への $\mathrm{Fe}$ 移行量 $(\mathrm{mol} / \mathrm{d}), \operatorname{TrP}$ は 污泥へのリン移行量 (mol/d) , TrP7 は Run7 におけ

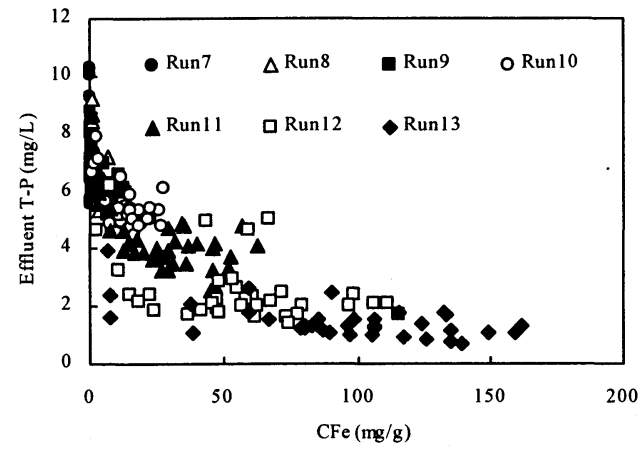

Fig. 8 Relationship between $\mathrm{CFe}$ and the effluent T-P.

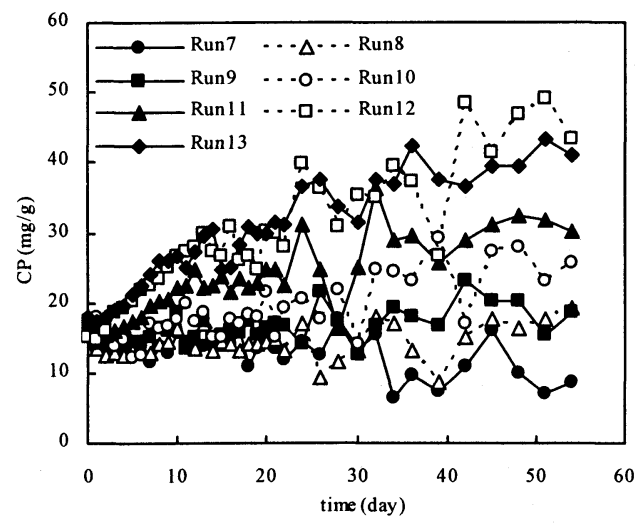

Fig. 9 Change of $\mathrm{CP}$. 
る污泥へのリン移行量 (mol/d) である. $\Delta \mathrm{Fe} / \Delta \mathrm{P}$ と 添加した Fe/P モル比との関係を求めると, Fig. 10 のとおりであった. Fe 添加量が 0 に近いと $\Delta \mathrm{Fe} / \Delta \mathrm{P}$ $=0.5$ となり, Fe 1 モルに対してリンが最大 2 モルの 比率で污泥へ移行したといえる.このことは, $\mathrm{Fe}$ と リンが単純に $\mathrm{FePO}_{4}$ として不溶化し除去されるのみ でなく, 複雑な凝集機構により污泥に移行している ことを示唆している ${ }^{15}$.

湖沼水中においてリンは, $\mathrm{FePO}_{4}$ として沈殿すると 同時に $\mathrm{Fe}(\mathrm{OH})_{3}$ への吸着によって共沈するとされて いる ${ }^{16)}$. さらに, リンは $\mathrm{Fe}$ の酸化物や水酸化物に入 りこみ不溶化するとされ， 3 価 $\mathrm{Fe}$ とリンの沈殿生成 物は $\mathrm{Fe} \cdot\left(\mathrm{H}_{2} \mathrm{PO}_{4}\right)_{\mathrm{n}} \cdot(\mathrm{OH})_{3-\mathrm{n}}$ と表されることがある ${ }^{17)}$. また, 土袞中の酸化鉄とリン酸イオンの間で 2 個の 水酸化物イオンと 1 個のリン酸イオンが置き換わり, 多量のリンが $\mathrm{Fe}$ に固定されることがある ${ }^{18)}$. 排水処 理のリン除去において中性付近では $\mathrm{Fe}, \mathrm{Al}$ のほと んどが $\mathrm{Fe}(\mathrm{OH})_{2}{ }^{+}$または $\mathrm{Fe}(\mathrm{OH})_{3}, \mathrm{Al}(\mathrm{OH})_{3}$ で存在し, $\mathrm{Fe}^{3+}, \mathrm{Al}^{3+}$ はわずかであるとしている ${ }^{10)}$ ここれらの ことから, 本実験においても, リンは $\mathrm{FePO}_{4}$ として 沈殿寸る他に, $\mathrm{Fe}$ の酸化物や水酸化物に凝集して水 中から除去されたものと考えられる.

他方, Fe の添加量が多い Run では, Fe 1 モルの 移行に対するリンの移行量は減少し, Run13 におい ては $\Delta \mathrm{Fe} / \Delta \mathrm{P}>2$ となっている.このとき, リンを 凝集していない $\mathrm{Fe}$ の酸化物や水酸化物が污泥中に 多量に存在しているといえるが，この場合において も処理水中にリンが残存している.このことは, リ ンは $\mathrm{Fe}$ の水酸化物や酸化物に瞬時に凝集するので はなく，比較的緩やかに凝集反応が進行することを 示唆している.

Xie et al. ${ }^{19}$ によれば, PACを用いた 2 次処理水の 凝集乃過実験で, リン除去率は運転開始後から緩や かに増加し 9 時間で 90\%以上に達した. その理由と して, Alで凝集した污泥がろ層内において, さらに リン酸イオンを吸着したためとしている．本実験で も, 污泥を形成した凝集剤が, 緩やかな速度でリン を除去し続けたと考えられる.

また, 処理水中の平均 $\mathrm{Fe}$ 濃度は Run8 Run13 で それぞれ $0.2,0.3,0.4,0.8,1.7,2.5 \mathrm{mg} / \mathrm{L}$ 曝気槽 混合液中の $\mathrm{Fe}$ 濃度に比べ遙かに低く,このことは 水中の $\mathrm{Fe}$ は速やかに污泥に移行したことを示唆し ている．これは，中性付近では Fe のほとんどが $\mathrm{Fe}(\mathrm{OH})_{3}$ として沈殿したためであると考えられる ${ }^{10)}$.

これらのことから, 曝気槽に添加された $\mathrm{Fe}$ は速 やかに污泥に移行した後, 比較的緩やかな速度をも って水中のリンを凝集して除去するといえる.

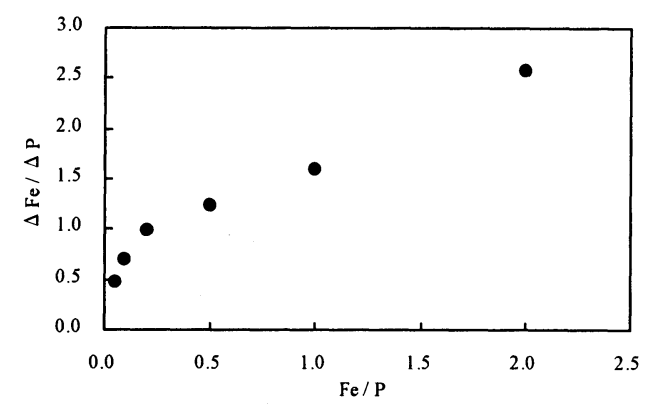

Fig. 10 Relationship between the molar ratio of the added $F e$ to the influent $P$ and the molar ratio of $\Delta \mathrm{Fe} / \Delta \mathrm{P}$.

\section{e）污泥中凝集剤およびリン含有率}

原ほか ${ }^{20}$ は凝集剤として Al を用いた活性污泥プ ロセスのモデリングにおいて, $\mathrm{Al}$ を $\mathrm{AlPO}_{4}$ と $\mathrm{Al}(\mathrm{OH})_{3} \cdot\left(\mathrm{PO}_{4}^{-3}\right)_{\mathrm{n}}$ とに分けて考えている. そこでは $\mathrm{n}<1$ としていることから, $\mathrm{Al}(\mathrm{OH})_{3}$ をリンを凝集し ているものと，凝集していないものに分けて考える ことができるといえる．ここでも，污泥中の $\mathrm{Fe}$ を リンを凝集しているものと凝集していないものに分 けて考察する.

前者の含有率を $\mathrm{FeP}(\mathrm{mgFe} / \mathrm{gSS})$ ，後者の含有率 を $\mathrm{FeA}(\mathrm{mgFe} / \mathrm{gSS})$ とし, 両者の合計が $\mathrm{CFe}$ であ る（式（5））.

$$
\mathrm{CFe}=\mathrm{FeP}+\mathrm{FeA}
$$

$\mathrm{Fe} 1$ モルがリン $\alpha$ モルを凝集して（ $\alpha$ は 1 以上） 污泥中に移行させるものとする. FeA とはすなわち, リンを凝集しておらずリン凝集能力を有する水酸化 鉄または酸化鉄である。水酸化鉄（Stumm， Morgan ${ }^{17)}$ はほとんどが $\mathrm{FeOOH}$ で存在するとしてい る）には $\alpha-\mathrm{FeOOH} \mathrm{(geothite} \mathrm{)} \mathrm{,} \beta-\mathrm{FeOOH}$ (akaganeite),$\quad \gamma$-FeOOH (lepidocrocite) などが, また酸化鉄には $\alpha-\mathrm{Fe}_{2} \mathrm{O}_{3}$ (hematite) ， $\quad \gamma-\mathrm{Fe}_{2} \mathrm{O}_{3}$ (maghemite), $\mathrm{Fe}_{3} \mathrm{O}_{4}$ (magnetite) などがあるとさ れている， $\mathrm{FeA}$ は概ねアモルファスの形態を持つこ れらの水酸化鉄または酸化鉄と考えられる. 一方, $\mathrm{FeP}$ とは FeA とリンが凝集した物質である.

TrFe のうち $\mathrm{FeP} / \mathrm{CFe}$ の割合の部分の Feがリンを 凝集していること, 凝集によるリン移行量は TrP Trp7 であることから $\alpha$ は式（6）で表される.

$$
\alpha=1 /(\operatorname{TrFe} \cdot(\mathrm{FeP} / \mathrm{CFe}) /(\operatorname{TrP}-\operatorname{TrP} 7))
$$

式（4）を用いて， $\alpha$ はさらに式（7）で表される. 


$$
\begin{aligned}
\alpha & =1 /(\Delta \mathrm{Fe} / \Delta \mathrm{P} \cdot \mathrm{FeP} / \mathrm{CFe}) \\
& =1 /(\Delta \mathrm{Fe} / \Delta \mathrm{P} \cdot(1-\mathrm{FeA} / \mathrm{CFe}))
\end{aligned}
$$

したがって, 式（8）を得る.

$$
\mathrm{FeA} / \mathrm{CFe}=1-1 /(\alpha \cdot \Delta \mathrm{Fe} / \Delta \mathrm{P})
$$

Run8 Run13の $\Delta \mathrm{Fe} / \Delta \mathrm{P}$ （運転期間中の平均值）を 用いて，式（8）の関係を図示すると Fig. 11 となる. $\alpha$ が大きいほど, または $\mathrm{Fe}$ 添加量の多い Run ほど, $\mathrm{FeA} / \mathrm{CFe}$ が大きく，リンを凝集する $\mathrm{Fe}$ 量が少ない といえる.

Run8 において $\alpha$ は 2 以上であり, Fe 1 モルに対 して 2 モル以上のリンを凝集している. しかし， Run13 においては FeA / CFe が 0.6 以上であり, 添加 した Fe 量の半分以上がリンを凝集していない.こ のように凝集剤の添加条件が異なれば，污泥中の $\mathrm{Fe}$ の形態も異なることがわかる.

さらに，污泥中のリンを $\mathrm{Fe}$ と凝集しているもの と微生物に摄取されているものに分けて考察する.

前者の含有率を $\mathrm{PFe}(\mathrm{mgP} / \mathrm{gSS})$ ，後者の含有率を $\mathrm{BioP}(\mathrm{mgP} / \mathrm{gSS})$ とし，両者の合計が CP である (式 (9)）.

$$
\mathrm{CP}=\mathrm{PFe}+\mathrm{BioP}
$$

$\mathrm{CP}$ の測定値を用い, $\mathrm{CP}$ から $\mathrm{BioP}$ を減じて $\mathrm{PFe}$ を求めることができ，さらに $\mathrm{FeA}$ を式（10）にて求 めることができる.ここで， 55.85 および 30.97 はそ れぞれ $\mathrm{Fe}$ およびリンの分子量を示す.

$$
\begin{gathered}
\mathrm{FeA}=\mathrm{CFe}-(\mathrm{CP}-\mathrm{BioP}) \cdot(55.85 / 30.97) \\
=\mathrm{CFe}-1.80 \cdot \mathrm{PFe} / \alpha
\end{gathered}
$$

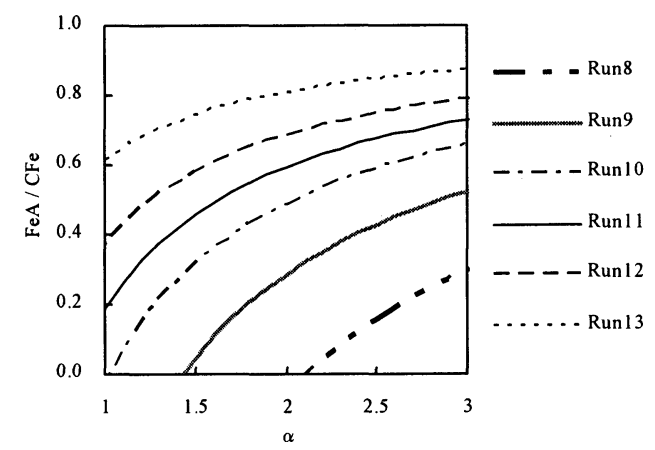

Fig. 11 Relationship between $\alpha$ and FeA / CFe.
Fig. 12 は $\alpha=1$ とした場合の Run13の FeA, FeP, $\mathrm{CFe}$ の変化を計算した結果である. ここで, BioP は $\mathrm{Fe}$ 無添加の Run7 運転後期の $\mathrm{CP}$ 平均值 $9.5 \mathrm{mg} / \mathrm{g}$ とし ている. 運転開始後は FeA, FeP 両者とも徐々に増加 したが，その絶対量には差異が見られ $\mathrm{FeP}$ のほぼ 1.5 〜2 倍の FeA が存在した. 全体を通して FeA / CFe は ほぼ 0.6 であり,これは Fig. 11 とも一致している.

凝集剤添加モル比 1 以上においても処理水にリン が残存していたことは, このリンを凝集していない $\mathrm{Fe}$ である $\mathrm{FeA}$ の存在に起因している. また, 通常 は Fe とリンが 1:1 $(\alpha=1)$ で反応するとされている が, 今回の実験では, 凝集剂の添加条件によっては $\alpha$ が 1 以上になることも判明した. これらのことか ら, 凝集剤 1 モルでリンを多量に凝集できるように $\alpha$ を高くし，また凝集剤の大部分がリンを凝集する ように $\mathrm{FeA}$ を低くすることにより，凝集剂添加量の 削减が可能と考えられる.

\section{（3）污泥中凝集剤の挙動}

凝集剤の污泥一の蓄積実験において 1 日あたりの $\mathrm{Fe}$ 添加量を u (mg/d), 曝気槽内の固形物量を $\mathrm{S}$ $(\mathrm{g})=\mathrm{MLSS} \cdot \mathrm{V} / 1000$ とすると, Fe に着目した物 質収支より式（11）が成り立つ.

$\mathrm{CFe} \cdot \mathrm{S}+\mathrm{u} \cdot \mathrm{dt}=(\mathrm{CFe}+\mathrm{dCFe}) \cdot(\mathrm{S}+\mathrm{dS})$

曝気槽の MLSS は, Fe の添加によって増加する ことが考えられたが, Table 4 のように Run13 でや や高い他は大差がみられなかった，そこで，ここで は近似的に S を一定として式（11）を解くと, 式（12）の解析解を得ることができる.

$$
\begin{aligned}
\mathrm{CFe}=\mathrm{u} \cdot \mathrm{SRT} / \mathrm{S}+ & \left(\mathrm{CFe}_{0}-\mathrm{u} \cdot \mathrm{SRT} / \mathrm{S}\right) \\
\cdot & \exp (-\mathrm{t} / \mathrm{SRT})
\end{aligned}
$$

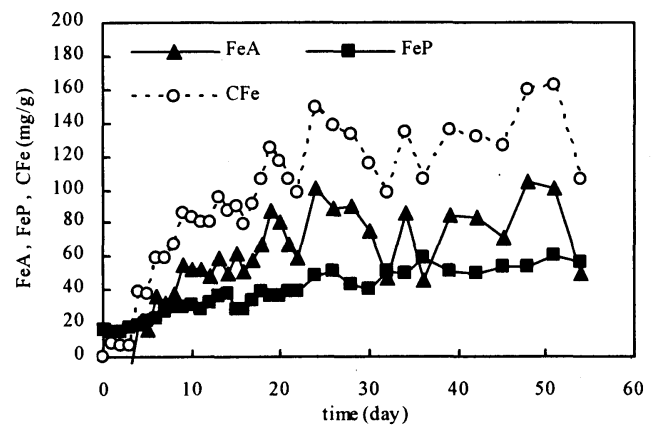

Fig. 12 Change of $\mathrm{FeA}, \mathrm{FeP}$ and $\mathrm{CFe}$ with $\alpha=1$ in Run13. 
ここで， $\mathrm{CFe}_{0}$ は実験開始時の $\mathrm{CFe}$ でほぼ $0 \mathrm{mg} / \mathrm{g}$ である. $\mathrm{t}$ が増加すると $\mathrm{CFe}$ は増加するが, 増加分の 右辺第 2 項は次第に小さくなり, 最大值 $\mathrm{u} \cdot \mathrm{SRT} / \mathrm{S}$ に収束する. S / SRT は 1 日当たりの污泥の增殖量 であるから，u・SRT / S は 1 日当たりの污泥増殖量 に対する凝集剤添加量の比率を示す。これは， $\mathrm{u} ま$ たは SRTが増えれば CFe は増加し, S が増えれば減 少することを意味する.

式（12）を用いた $\mathrm{CFe}$ の計算值は Fig. 13 のとお りで, Fig. 7 の実測值とほぼ等しい変動を示した. したがって, 凝集剂添加開始からの $\mathrm{CFe}$ の蓄積を 式（12）を用いて算出できるといえる. また， $\mathrm{CFe}$ の収束值について, 実験での結果と式 (12) での計 算値を比較して Fig. 14 に示した. 図中のすべての プロットはほぼ傾き 1 の直線上に存在し, 両者はよ く一致した.

ここで式（12）に凝集剂添加を停止した場合の $\mathrm{u}=0$ を代入すると式（13）を得ることができる.

$$
\mathrm{CFe}=\mathrm{CFe}_{0} \cdot \exp (-\mathrm{t} / \mathrm{SRT})
$$

凝集剤の減少実験から k と 1/ SRT が等しいこと がわかっており，式（13）の1/ SRTを kに置き換 えると, 式（2）と同様になる，すなわち式（12） は, 凝集剤の減少過程においても用いることができ る.したがって，污泥中の凝集剤含有率は Fig. 15 に示したように, その蓄積時においても, 平衡時に おいても, また減少時においても, 凝集剤の添加量 から引き抜きによる搬出量を減じて求めることがで きる.

\section{（4）リン除去モデルの考察}

a) リン除去モデル

凝集剤の污泥への蓄積実験から, 添加された $\mathrm{Fe}$
は酸化物や水酸化物として速やかに污泥に移行した 後, 比較的緩やかな速度をもってリンを凝集除去す るものと考えられた。この知見をもとに，凝集によ るリン除去プロセスの動力学的モデル化を行った. まず，污泥中にはリンを凝集した $\mathrm{Fe}$ と凝集していな い Fe が混在し, また污泥中のリンも, 微生物に摂取 されているものと $\mathrm{Fe}$ に凝集したものとに分けて考え, さらに以下を仮定した（Fig.16および Table 6）.

(1) 添加された Fe は全量が速やかにリンを凝集し ていない $\mathrm{Fe}(\mathrm{FeA})$ に移行する.

(2) FeA は曝気槽中の $\mathrm{FeA}$ 濃度および溶解性リン濃 度（Pe (mg/L) ) に比例した速度（速度定数 $\beta$ $(\mathrm{L} / \mathrm{mg} / \mathrm{d}))$ でリンを凝集した $\mathrm{Fe}(\mathrm{FeP})$ に変化する. (3) 流入したリンは, 一部は微生物攝取により

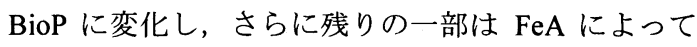
凝集除去される.このとき, リンは $\mathrm{P} / \mathrm{Fe}$ モル比 $\alpha$ で $\mathrm{Fe}$ に凝集するとする. 水中の残存リンは処理水 （濃度 Pe）として流出する.

(4) $\mathrm{FeA}, \mathrm{FeP}, \mathrm{BioP}, \mathrm{PFe}$ の一部は, 污泥引き抜き (Es $(\mathrm{g} / \mathrm{d}))$ ) によって搬出される.

なお, $\mathrm{PFe}$ と BioP の和が CP である.

添加 $\mathrm{Fe}$ 量を u $(\mathrm{mg} / \mathrm{d})$ とし, 曝気槽内の固形物 量を S $(\mathrm{g})=\mathrm{MLSS} \cdot \mathrm{V} / 1000$ とすると, $\mathrm{FeA}$ の変化 は式（14）で与えられる.

$$
\begin{gathered}
\mathrm{dFeA} / \mathrm{dt}=(\mathrm{u}-\mathrm{FeA} \cdot \mathrm{Es} \\
-\beta \cdot(\mathrm{FeA} \cdot \mathrm{MLSS} / 1000) \cdot \mathrm{Pe} \cdot \mathrm{V}) / \mathrm{S}
\end{gathered}
$$

また, FePの変化は式（15）となる.

$$
\mathrm{dFeP} / \mathrm{dt}=
$$

$$
(\beta \cdot(\mathrm{FeA} \cdot \mathrm{MLSS} / 1000) \cdot \mathrm{Pe} \cdot \mathrm{V}-\mathrm{FeP} \cdot \mathrm{Es}) / \mathrm{S}
$$

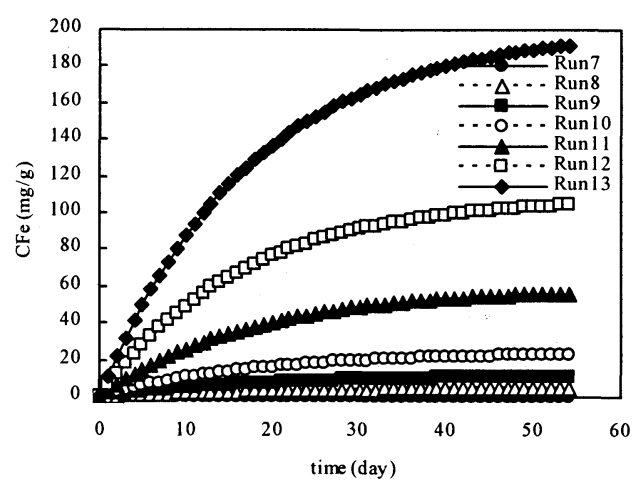

Fig. 13 Calculation of CFe with eq.12.

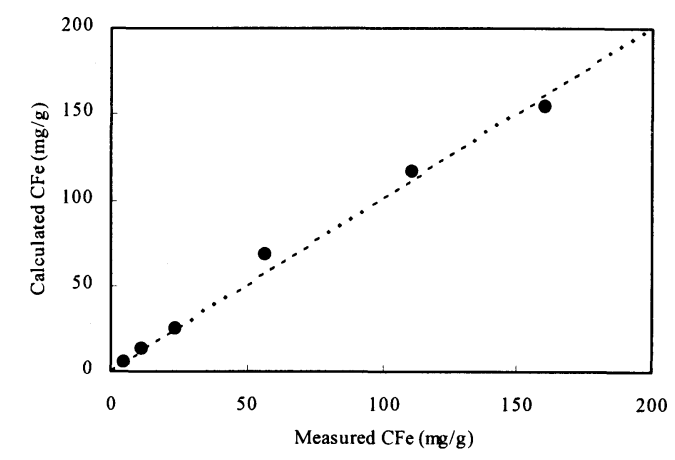

Fig. 14 Relationship between measured $\mathrm{CFe}$ and calculated $\mathrm{CFe}$. 


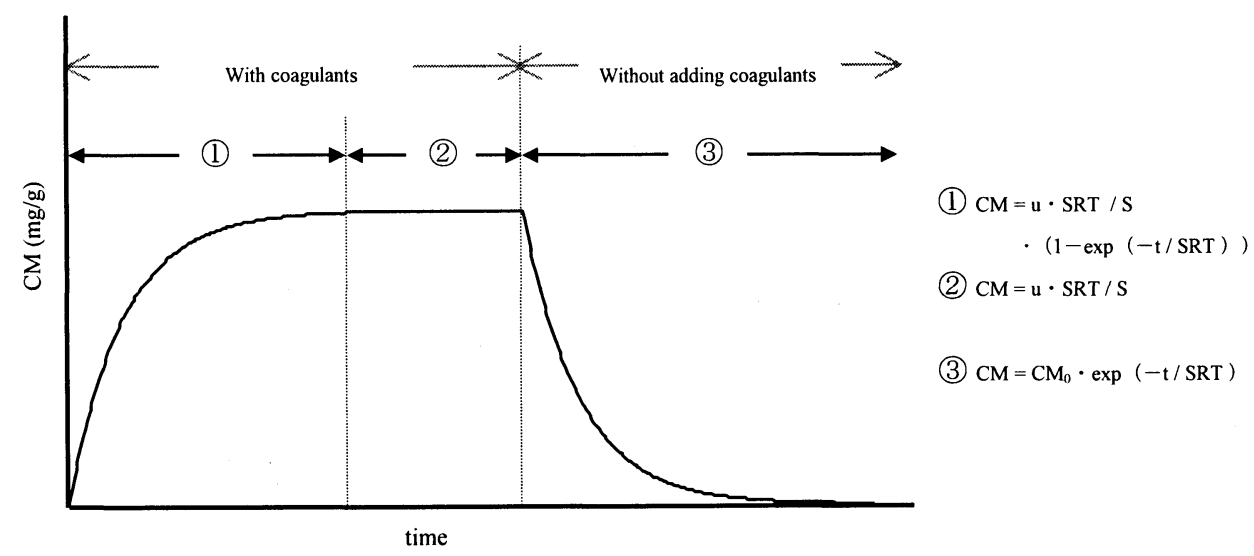

Fig. 15 Summary of CM accumulation and reduction.

一方, $\mathrm{PFe}$ は $\mathrm{FeP}$ の $\alpha \cdot 0.555$ 倍であるから， $\mathrm{PFe}$ の変化は式（16）となる. ただし 0.555 は P と $\mathrm{Fe}$ の分子量比（30.97/55.85）である.

$$
\begin{gathered}
\mathrm{dPFe} / \mathrm{dt}= \\
(0.555 \cdot \alpha \cdot \beta \cdot(\mathrm{FeA} \cdot \mathrm{MLSS} / 1000) \cdot \mathrm{Pe} \cdot \mathrm{V} \\
-\mathrm{PFe} \cdot \mathrm{Es}) / \mathrm{S}
\end{gathered}
$$

$\mathrm{Pe}$ の変化は, 流入リン量を $\mathrm{Pi} \cdot \mathrm{Q}(\mathrm{mg} / \mathrm{d})$ とし, 流入流出, BioP としての搬出および $\mathrm{PFe}$ への変化か ら, 式 (17) となる.

$$
\mathrm{dPe} / \mathrm{dt}=((\mathrm{Pi}-\mathrm{Pe}) \cdot \mathrm{Q}-\mathrm{BioP} \cdot \mathrm{Es}
$$

$-0.555 \cdot \alpha \cdot \beta \cdot(\mathrm{FeA} \cdot \mathrm{MLSS} / 1000) \cdot \mathrm{Pe} \cdot \mathrm{V}) / \mathrm{V}$

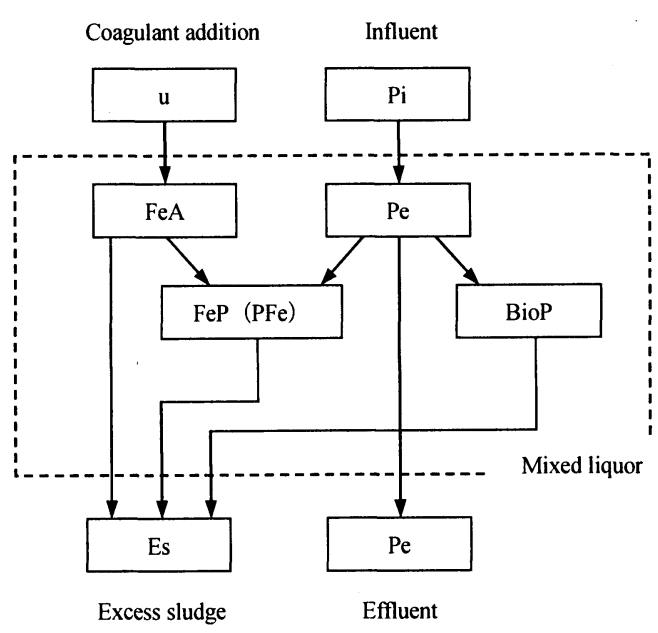

Fig. 16 Summary of $P$ removal model.
ここで各 Run の BioP は，污泥中に Fe と凝集した リンが含まれないと考えられる Run7 における運転 後期の CP として $9.5 \mathrm{mg} / \mathrm{g}$ を用いた。 また, Es は S を SRTで除することにより算出した.

本モデルにおいては FeA がリンを凝集して FePに なるとき, その反応速度が $\mathrm{FeA}$ の濃度とリン濃度に 比例するとした。 なお, リン濃度には比例せず $\mathrm{FeA}$ のみに比例するとしたケースについても解析を行っ たが, $\mathrm{Pe}$ の計算值は実測の処理水 $\mathrm{PO}_{4}-\mathrm{P}$ の変動とは 異なったパターンを示した.

$\mathrm{Fe}$ 添加によって MLSS が増加することが知られ ている. 本モデルでは $\mathrm{Fe}$ 添加によって, $\mathrm{Fe}$ 化合物

(FeA および $\mathrm{FeP})$ と凝集したリン化合物（PFe） 分の重量が増加するとした. MLSS 測定の際には,

Table 6 Components and parameters of $P$ removal model.

\begin{tabular}{|l|c|c|}
\hline \multicolumn{2}{|c|}{ Components in the activated sludge } & Unit \\
\hline Total $\mathrm{Fe}$ content & $\mathrm{CFe}$ & $\mathrm{mg} / \mathrm{g}$ \\
\hline $\mathrm{Fe}$ content combined with $\mathrm{P}$ & $\mathrm{FeP}$ & $\mathrm{mg} / \mathrm{g}$ \\
\hline Fe content without $\mathrm{P}$ & $\mathrm{FeA}$ & $\mathrm{mg} / \mathrm{g}$ \\
\hline Total $\mathrm{P}$ content & $\mathrm{CP}$ & $\mathrm{mg} / \mathrm{g}$ \\
\hline $\mathrm{P}$ content combined with $\mathrm{Fe}$ & $\mathrm{PFe}$ & $\mathrm{mg} / \mathrm{g}$ \\
\hline Biological $\mathrm{P}$ content & $\mathrm{BioP}$ & $\mathrm{mg} / \mathrm{g}$ \\
\hline
\end{tabular}

\begin{tabular}{|l|c|c|}
\hline \multicolumn{2}{|c|}{ Other components } & Unit \\
\hline Flow rate & $\mathrm{Q}$ & $\mathrm{L} / \mathrm{d}$ \\
\hline Influent P concentration & $\mathrm{Pi}$ & $\mathrm{mg} / \mathrm{L}$ \\
\hline Effluent P concentration & $\mathrm{Pe}$ & $\mathrm{mg} / \mathrm{L}$ \\
\hline Fe addition & $\mathrm{u}$ & $\mathrm{mg} / \mathrm{d}$ \\
\hline Weight of excess sludge & $\mathrm{Es}$ & $\mathrm{g} / \mathrm{d}$ \\
\hline Volume of aeration tank & $\mathrm{V}$ & $\mathrm{L}$ \\
\hline MLSS & $\mathrm{MLSS}$ & $\mathrm{mg} / \mathrm{L}$ \\
\hline Total solids in aeration tank & $\mathrm{S}$ & $\mathrm{g}$ \\
\hline
\end{tabular}

\begin{tabular}{|l|c|c|}
\hline \multicolumn{2}{|c|}{ Parameters } & Unit \\
\hline Molar amount of P combined with 1 molar Fe & $\alpha$ & \\
\hline Reaction rate from FeA to FeP & $\beta$ & $\mathrm{L} / \mathrm{mg} / \mathrm{d}$ \\
\hline
\end{tabular}


$\mathrm{Fe}$ およびリン化合物はそれぞれ $\mathrm{Fe}_{2} \mathrm{O}_{3}$ ( $\mathrm{Fe}$ 重量の 1.43

倍）および $\mathrm{P}_{2} \mathrm{O}_{5}$ （P 重量の 2.29 倍）として存在すると して，MLSSの変化量を式（18）によって表した.

$\mathrm{dMLSS} / \mathrm{dt}=(1.43 \cdot(\mathrm{u}-\mathrm{FeA} \cdot \mathrm{Es}-\mathrm{FeP} \cdot \mathrm{Es})$

$+2.29 \cdot(0.555 \cdot \alpha \cdot \beta \cdot(\mathrm{FeA} \cdot \mathrm{MLSS} / 1000) \cdot \mathrm{Pe} \cdot \mathrm{V}$

$$
-\mathrm{PFe} \cdot \mathrm{Es})) / \mathrm{V}
$$

モデル式に基づく数值計算では, まず式（14）に よって $\mathrm{FeA}$ を計算し, ここで求まった $\mathrm{FeA}$ を, 式 （15），式（16），式（17）にそれぞれ代入して $\mathrm{FeP}, \mathrm{PFe}, \mathrm{Pe}$ を計算する。また, これらを式

（18）に代入して MLSS を算定する. 求まった FeA と $\mathrm{FeP}$ の合計値を $\mathrm{CFe}$ とし, $\mathrm{FeA} / \mathrm{CFe}$ を計算する. MLSS の実測值は Run13 を除き，顕著な増加はみら れず，モデルの計算においても Run13 を除いては顕 著な增加はなかった。このことは, 凝集剂添加量を 削減した場合, 凝集剂添加活性污泥法の欠点とされる 污泥発生量の増加を抑制できることを示唆している.

b) パラメータ $\alpha, \beta$

本モデルでは, $\mathrm{FeA}$ がリンを凝集する際の $\mathrm{P} / \mathrm{Fe}$ モ ル比 $\alpha$ および凝集反応の速度定数 $\beta$ をパラメータ としてモデル式を作成している． $\alpha$ は Run や運転時 期によって, $\mathrm{FeA}$ と $\mathrm{Pe}$ の濃度変化に起因して変化 すると考えられる。一方， $\beta$ は Run や運転時期によ らず一定と考えた.

運転後期の定常状態においては，式（14）の左辺 が 0 になるために $\beta$ と FeA の関係を得ることができ る. さらに式 (7) の FeA と $\alpha$ の関係を用い, $\beta$ を 変動させて $\alpha$ を計算した. その変動を評価したとこ ろ, $\beta<0.09$ では Run13 の $\alpha$ が他の Run の $\alpha$ の值を 超える場合があった。これは Fig. 10 の結果より Fe 添加量の低い Run で $\alpha$ が高いと予想されることから 不適とした. また $\beta>0.09$ では $\alpha$ が 1 よりも低くな る場合があり，これは $\alpha$ の定義（ $\alpha>1 ）$ を満足しな いことから不適とした. よって $\beta$ の最適值を 0.09 と した. $\beta=0.09$ を用いて $\alpha$ を計算すると Run8〜 Run13 でそれぞれ $2.4,1.6 ， 1.2 ， 1.0 ， 1.0 １ .0$ とな った.

また, 曝気槽内の $\mathrm{Pe} / \mathrm{FeA}$ モル比を式 (19) で求 め, $\alpha$ との関係をプロットすると Fig. 17 のとおり 直線関倸が得られ， $\alpha$ は $\mathrm{Pe} / \mathrm{FeA}$ モル比によって決 定されるといえる.

$$
\mathrm{Pe} / \mathrm{FeA} \text { モル比 = }
$$

$\mathrm{Pe} /(\mathrm{FeA} \cdot \mathrm{MLSS} / 1000) \cdot(55.85 / 30.97)$

\section{c）污泥中 $\mathrm{Fe}$ の分別評価}

上記のように決定した $\alpha, \beta$ を用いて, $\mathrm{FeP}$ およ び PFeを計算した。ささらに CFeおよび $\mathrm{CP}$ を計算し, 実測值と比較をしたところ，Fig. 18 のように全 Run で両者はほぼ一致した結果が得られた。

次に，運転後期の $\mathrm{CFe}$ (計算值) 中の $\mathrm{FeA}$ の割合 ( FeA / CFe) を求めると Fig. 19 のとおりであり, Run8〜Run10 の Fe 添加量の少ない Runにおいては 0.1 程度でほぼ一定であるが，Run11〜Run13 におい てはそれぞれ $0.17,0.33,0.60$ と, $\mathrm{Fe}$ 添加量の増加 に伴って増加していた. FeA の存在は, 曝気槽への $\mathrm{Fe}$ 添加を停止した後も污泥が水中のリンを除去でき る能力を有することを示している. FeA / CFe が高 い污泥では凝集剂添加を停止してもリン除去性能を 維持するといえ, これは污泥中凝集剤の減少実験や 実処理場でみられた現象を説明するものである ${ }^{11)}$. 本モデルによって, $\mathrm{CFe}$ を $\mathrm{FeA}$ と $\mathrm{FeP}$ に分別して算 定し，それによって污泥のリン凝集能力の評価が可 能になったといえる.

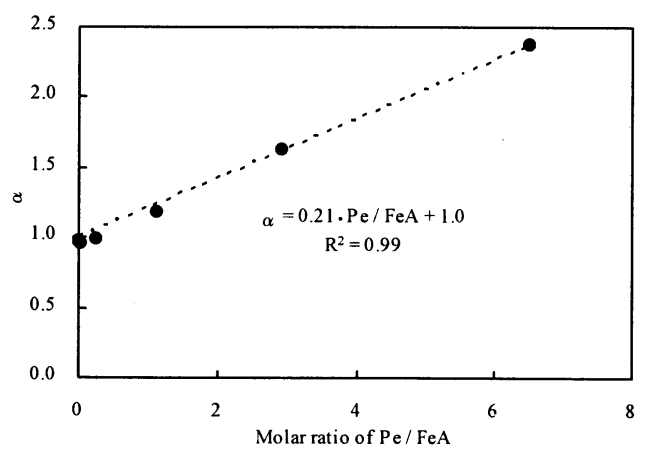

Fig. 17 Relationship between $\alpha$ and the molar ratio of $\mathrm{Pe} / \mathrm{FeA}$.

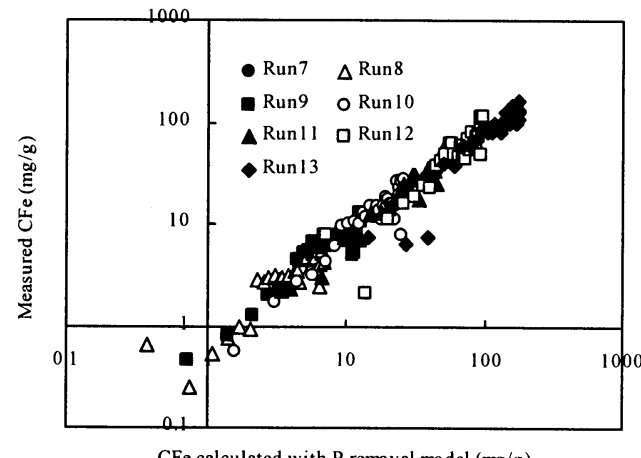

Fig. 18 Relationship between $\mathrm{CFe}$ calculated with $\mathrm{P}$ removal model and measured $\mathrm{CFe}$. 


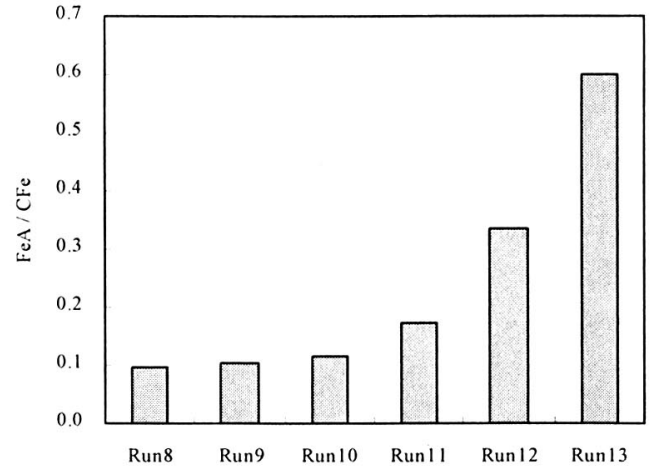

Fig. $19 \mathrm{FeA} / \mathrm{CFe}$ in Run 8 Run 13.

\section{d）污泥への Fe の蓄積過程}

Fig. 20 は，先のパラメータを用いてRun13におけ る運転開始後からの FeA および $\mathrm{CFe}$ の変動を計算 したものである. $\mathrm{FeA}, \mathrm{CFe}$ ともに徐々に増加した 後一定值に収束している. 運転初期には $\mathrm{CFe}$ のほと んどが FeA であるが，次第に FeA の割合が減少し て運転後期には 0.6 となった. $\mathrm{FeA}$ と $\mathrm{CFe}$ の変動の 計算結果は, Run8〜Run12 でも同様の傾向であった. 運転後期における混合液中の $\mathrm{Fe}$ とリンの各形態 濃度の計算結果は, Fig. 21 で示されるような分布で あり, FeA, FeP, PFe は污泥へ蓄積した. CFe は, Run8〜Run13 でそれぞれ 6.9，13，26，52，97， $180 \mathrm{mg} / \mathrm{g}$ であった。

連転期間中の $\mathrm{FeA}$ および $\mathrm{CFe}$ と $\mathrm{Pe}$ の関係は Fig. 22 のとおうりであり，FeA と Peには対応関係が 認められた。これは処理水リン濃度は $\mathrm{CFe}$ ではなく

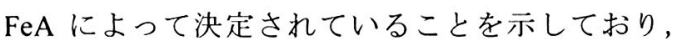
$\mathrm{FeA}$ を用いて処理水リン濃度を制御することができ る.ただし，凝集剤を連続的に添加して CFe が定常 状態に達した時点ならば， $\mathrm{CFe}$ も処理水リン濃度の 制御に十分用いられよう。このように, 削減目標の 処理水リン濃度に見合う $\mathrm{FeA}$ を決定し, その值以上 に $\mathrm{FeA}$ を維持するように凝集剤を添加することによ って安定したリン除去が期待できる.

污泥中凝集剂の減少実験結果に対してもリン除去 モデルを適用したところ，処理水リン濃度と $\mathrm{CFe}$ の 実測値と計算值がほぼ一致した結果が得られた。

このように，本モデルを用いて凝集戍およびリン の污泥中の挙動をマクロに推定することができ, 処 理水リン濃度の直接的な影響因子である $\mathrm{FeA}$ の濃度 を算定することができる。この算定結果を応用して， さらには凝集剤の最適な添加量を理論的に決定する ツールとして本モデルを利用することができると考 える。

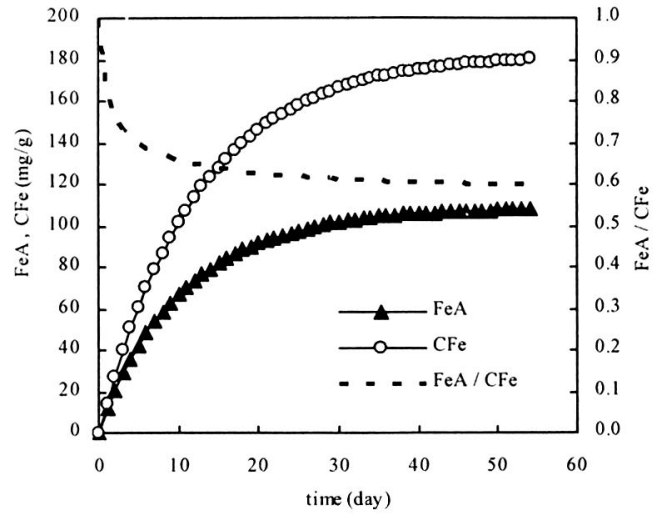

Fig. 20 Calculated $\mathrm{FeA}$ and $\mathrm{CFe}$ in Run 13.

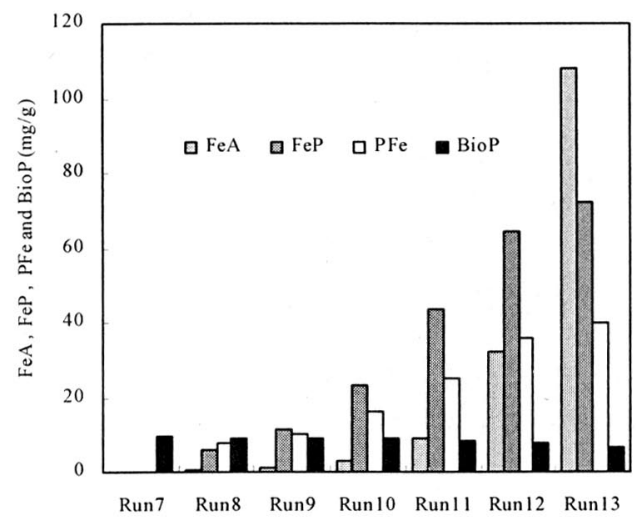

Fig. 21 Component in sludge of Run7 Run13.

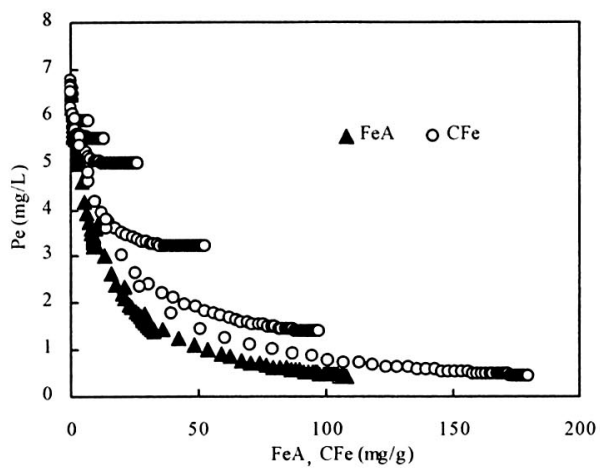

Fig. 22 Relationship between $\mathrm{FeA}, \mathrm{CFe}$ and Pe.

\section{4. 結論}

活性污泥法における凝集剤添加の室内実験を行い, リン除去用凝集剂の減少および蓄積を検討した結果, 以下の知見を得た。 
1）凝集剂添加を停止すると, 污泥中凝集剤含有率 （CM）は活性污泥の增殖に伴い希釈され指数 関数的に減少した.

2） $\mathrm{CM}$ が高い場合においては処理水 T-P は低濃度 に抑えられており, CM の増加がリン除去に有 効であった.

3）凝集剂を連続添加した場合には，凝集剂添加モ ル比の低いRunでFe 1 モルに対してリンが 2 モ ルの比率で污泥に移行していた.

4）凝集剤の污泥中の挙動を計算により求めること でき, 凝集剤の蓄積, 平衡, 减少時において $\mathrm{CM}$ の計算值と実測值はよく一致していた.

5）曝気槽に添加された Fe は速やかに污泥に移行 した後, 比較的緩やかな速度をもって水中のリ ンを凝集して除去すると考えられた.

6）污泥中の Feおよびリンをそれぞれ 2 つに分別し た凝集プロセスを表す動力学的リン除去モデル を提案した。

7) リン除去モデルを用いることで污泥中のリンお よび Fe の挙動を推定することができ，さらに 最適な凝集剂添加量の決定に応用できる.

謝辞：立命館大学大学院理工学研究科在学中にご協 力いただいた田畑洋輔氏ならびに平岡史美氏に厚く 御礼申し上げます。

\section{参考文献}

1) Matsuo, T. : Japanese experiences in water pollution control and wastewater treatment technologies , Wat.Sci.Tech., 42, pp.163-172, 2000.

2）高橋正宏, 宮田純, 滝沢智, 国文剛: 供用中のり ん・窒素除去施設の設計, 運転に関するアンケート 調査結果, 下水道協会誌，31，pp.65-72，1994.

3）村田恒雄: 下水の高度処理技術, 理工図書, 東京, pp.166-235, 1992.

4) Janssen, P.M.J., Meinema, K. and van der Roest H.F. : Biological phosphorus removal, STOWA-IWA, London, pp.41-59, 2002.

5）大河内孝: 凝集剂添加活性污泥法一鉄塩添加が水処 理に与える効果一, 下水道協会誌, $31, \mathrm{pp} .23-28$, 1994.

6) Yamamoto-Ikemoto, R., Matsui, S., Komori, T. and Bosque-Hamilton, E.K. : Control of filamentous bulking and interactions among sulfur oxidation-reduction and iron oxidation-reduction in activated sludge using an iron coagulant, Wat.Sci.Tech, 38, pp.9-17, 1998.

7）鈴木穣 : 凝集剤添加活性污泥法と嫌気 - 好気活性污 泥法による排水中のリン除去, 資源環境対策, 29, pp.1014-1019， 1993.

8）松尾友矩編: 水質環境工学, 技報堂出版, 東京, pp.487-556, 1993.

9）日本下水道協会 建設省都市局下水道部：下水道施設 計画 - 設計指針と解説 後編 -1994 年度版一, 日 本下水道協会, 東京, pp.131-134, 1994.

10) Rittmann, B.E. and McCarty, P.L. : Environmental Biotechnology: Principles and Applications, McGrawHill, New York, pp.535-545, 2001.

11）見島伊織，中島淳 : リン除去型活性污泥法における 污泥中の凝集剤およびリンの挙動, 水環境学会誌, 26, pp.99-104, 2003.

12）奥野久羊 : 実施設における遠心濃縮併用凝集剂添加 嫌気好気法によるリン除去, 用水と廃水, 32 , pp.594-603, 1990.

13) Yamamoto, Y., Inoue, M., Nishimura, O., Inamori, Y. and Matsumura, M. : Development of phosphorus removal process of on-site domestic wastewater treatment systems using dripping method of thick iron solution, Japanese Journal of Water Treatment Biology, 38, pp.29-38, 2002.

14）山本泰弘, 三浦勇二, 井上充, 藤本尚志, 稲森悠平, 松村正利: 嫌気乃床・生物ろ過法における物理化学 的リン除去法導入による処理性能の評価, 日本水処 理生物学会誌, 38, pp.47-55, 2002.

15）見島伊織, 中島淳 : 凝集剤の活性污泥一の蓄積とリ ン除去特性, 日本水環境学会年会講演集, 第 36 回, pp.493, 2002.

16) Golterman, H.L. : Vertical movement of phosphate in freshwater, Environmental phosphorus handbook, Griffith, E.J., Beeton, A., Spencer, J.M. and Mitchell, D.T. eds., Wiley-Interscience, New York, pp.509-538, 1973.

17）スタム, W. , モーガン, J.J. : 一般水質化学, 共立 出版, 東京, pp.477-525, 1974.

18) Parfitt, R.L., Atkinson, R.J. and Smart, R.C. : The mechanism of phosphate fixation by iron oxides, Soil Sct.Soc.Amer.Proc., 39, pp.837-841, 1975.

19) Xie, W. , Kondo, M. and Naito, Y. : Study on phosphorus removal using a new coagulation system, Wat.Sci.Tech, 30, pp.257-262, 1994.

20）原直樹, 木村文智, 武本剛, 渡辺昭二 : 凝集剤添加 時の活性污泥プロセスのモデリング, 下水道研究発 表会講演集，38，pp.445-447，2001.

(2003. 2. 19 受付) 


\title{
CHARACTERISTICS OF PHOSPHORUS REMOVAL IN ACTIVATED SLUDGE PROCESS WITH COAGULANT ADDITION
}

\author{
Iori MISHIMA and Jun NAKAJIMA
}

In order to remove phosphorus from domestic wastewater it is useful to add coagulants to activated sludge process. The amount of coagulant addition is usually determined by the molar ratio of coagulant to phosphorus. The precise mechanism of the coagulation process of phosphorus removal in activated sludge has not been clarified yet. So coagulant reduction and accumulation experiments using activated sludge were conducted in order to reduce the amount of coagulant addition. From the results, the coagulation process was discussed using a new phosphorus removal model, in which the coagulant in activated sludge was divided into two fractions. The coagulant contents in the accumulation process as well as the effluent phosphorus concentration were effectively computed using the model. The model is suggested for application in the determination of the amount of coagulant addition. 